\title{
EVALUATING THE ROLE OF INTERNAL AUDIT AND ITS RELATION TO THE QUALITY OF FINANCIAL STATEMENT
}

\author{
${ }^{1}$ Luh Komang Merawati and ${ }^{2}$ Putu Diah Kumalasari \\ ${ }^{1,2}$ Mahasaraswati Denpasar University
}

\begin{abstract}
Purpose - This research aimed to obtain empirical evidence about the effect of accounting understandability, human resource competency and the role of internal audit as moderating variable on the quality of financial statement.

Design/methodology/approach - This research was conducted on all financial administration officials and treasurers of local government in Bangli Regency with the primary data was obtained from questionnaires which were distributed to respondents. Sample was determined through purposive sampling. The analysis technique used was the multiple linear regression analysis.

Findings - The results suggested that accounting understandability and the human resouce competency had positive effect on the quality of financial statement. Meanwhile, the relation between accounting understandibility and the quality of financial statement, the role of internal audit was not the moderating variable. Whereas, the effect of the role of internal audit was proven to moderate the relation between human resource competency and the quality of financial statement, with negative direction.
\end{abstract}

Practical Implications - The financial statement of local government is a form of accountability on the use of local finances as the implementation of regional autonomy and the operational of local government to provide useful information in decision making.

Originality/value - The quality of the said financial statement is determined by qualitative characteristics which are relevant, reliable, comparable and understandable, based on PP No. 71 of 2010.

Keywords Accounting Understandability, Human Resource Competency, Role of Internal Audit, Quality of Financial Statement

Paper Type Research Paper 


\section{INTRODUCTION}

The reformation of state finances in globalization era which is marked by the establishment of the law in state finances that is stated the importance of good governance, which is based on the principle of transparency and accountability. The reformation of state finances includes the reformation in accounting and government financial reporting. This is shown by an obligation to prepare the reports of state finances accountability in a form of government financial statement (Elsye, 2016:61). The increasing demand for trasparency should have made the government improve the quality of financial statement that contains financial informations required by various parties. The complete presentation of information and in accordance with the needs of users would lead to transparency and accountability of local government financial management. Financial and managerial accountability is an important dimension in realizing the government's credibility as a party that should be held accountable on the mandate that has been given by the public (Islamiyah, et al., 2017).

According to government regulation PP No. 71 of 2010, the quality of financial statement is determined by qualitative characteristics of financial statement which are relevant, reliable, comparable and understandable. When the information contained in local government financial statement meets those Vol. 28, No. 3 December 2020

(C) Centre for Indonesian Accounting and Management Research Postgraduate Program, Brawijaya University 
criterias, it is considered that the government is able to improve the quality of its financial statement.

PP No. 71 of 2010 which is the fundamental reference in accounting implementation in each goverment agencies in Indonesia, defines accounting as a process of identifying, recording, measuring, classifying, summarizing over all financial transactions and activities, reporting, and also interpreting the result. This accounting process would process all financial transactions and activities in each local government entities. This process produces information in a form of financial statement that would be used in managerial evaluation and desicion making process that would affect the implementation of regional finances in the following periods. To allow the process running smoothly, accounting understandibility is required in preparing the local government financial statement. So, to provide a qualified financial statement, it is required people who understand about accounting.

Accounting is a tool for the government to maintain regular records of fund receipts and disbursements, which subsequently in the final stages of the management control process, accounting is required in preparing financial statement. When someone does not have an understanding in accounting, it would be difficult to understand and make decision in financial reporting, and also there would be a lack of quality in the financial statement. Researches 
conducted by Diani (2014), Purwanti (2014), and Nudilah (2016) suggested that the level of accounting understandibility had a positive effect on the quality of financial statement. This is contrary to the result of research conducted by Nova (2015) which stated that the accounting understandibility had no effect on the quality of government financial statement.

Talking about the quality of financial statement, besides the accounting understandibility, human resource competency is also required so that the financial statement produced would meet the qualitative characteristics of financial statement. Competency describes the primary knowledge and performance standards required to successfully adjust a job. Competence refers to behavioral approach which means being able to carry out work effectively, success and excel (Sudarmanto, 2015: 58). Attention to quality is one of the components of competence to ensure that the entire work process is carried out accurately in accordance with the quality standards (Sudarmanto, 2015: 96). So in preparing financial statement, adequate competency is required so that the financial statement produced is qualified.

Humairoh (2013), Ihsanti (2014), Udiyanti (2014), and Wati, et al. (2014) suggested that competence had positive effect on the quality of government financial statement. This is contrary to the result of research conducted by 
Sukmaningtyas (2017) which suggested that human resource competency had negative significant effect on the quality of financial statement

The inconsistency of the results between the relation of accounting understandibility and human resource competency on the quality of financial statement requires a contingency approach. The factor that is believed to having an influence on the quality of financial statement is the role of internal audit. The role of government internal audit is an important management function in governance, both at central and local government (Zeyn, 2018). According to Sawyer (2005: 84) the role of internal audit is to evaluate the control system and supporting documentation as well as evaluating other activities in the organization. The internal control system is the foundation of creating the quality of financial reporting as the positive relation between internal audit function and the quality of financial reporting has been shown from previous studies (Prawitt, et al., 2008; Gramling, et al., 2011). Kewo and Afiah(2017) proved that internal audit have positive effect on the quality of financial statement and also suggested to local governments to be more serious in improving the implementation of internal audit. Similar to Gamayuni (2018) suggested that the local government should improve the policies, procedures, and coordination of the internal audit function in order to achieve qualified financial reporting. 
Nova (2015) stated that the inspectorate has the duty to determine the reliability of information produced by various units/working units as an integral part of local government organizations. The inspectorate as an internal auditor of the regional government is expected to be able to assist regional government in preparing qualified and reliable financial statement. This is supported by the result of the research conducted by Nova (2015) that suggested that the role of internal audit had positive effect on the quality of financial statement.

Based on PP No. 60 of 2008 internal control is carried out by the government internal supervisory apparatus that is district/city inspectorate, by conducting supervision through: auditing, reviewing, evaluating, monitoring and other supervisory activities, where inspectorates in carrying out their duties must be independent and objective. From the result of the evaluation, the inspectorate will provide input for corrections to the local apparatus so that the financial statement produced contains reliable information and is in accordance with the Governmental Accounting Standards. To see whether the financial statement that have been prepared is in accordance with the Governmental Accounting Standards and in accordance with the expected quality, is seen from the auditor's opinion.

The phenomenon regarding the quality of financial statement is interesting to be further reviewed. Audit opinion process is a decision-making Vol. 28, No. 3 December 2020

(C) Centre for Indonesian Accounting and Management Research Postgraduate Program, Brawijaya University 
process by the professional audit judgement of state auditor that considers public interest and others (Susanto, et al., 2019). The financial statement that had got adverse opinion and disclaimer of opinion, in preparing the statement were not in accordance with the standards of state financial audits where Badan Pemeriksa Keuangan/BPK (the state auditor) in providing audit opinions is based on at least four things, which are: (1) the conformity of the financial statement presentation with the Governmental Accounting Standards, (2) the adequacy of disclosure, (3) the compliance with laws and regulations, and (4) the effectiveness of the internal control system.

Based on BPK Summary of Examination Results 2014, in terms of accountability in financial management, assessments of local government financial report in 2014 that have not yet gained unqualified opinion was still around 76\% (Islamiyah, et al., 2017). So was in Bangli Regency, where BPK stated qualified opinion on the local government financial statement for the 2014 fiscal year. This opinion was increased from those received in the 2013 fiscal year where Bangli Regency had got disclaimer of opinion, and in 2015 Bangli Regency was the only regency in Bali that had got qualified opinion while 8 other regencies had got unqualified opinion.

Based on the background description above and by looking at the phenomenon that occured about the poor quality of the financial statement of 
the local government in Bangli Regency as proven by the result of the BPK audit that stated qualified opinion, even more so with the inconsistency of the results of the previous studies, this study aimed to obtain empirical evidence about the effect of accounting understandability, human resource competency and the role of internal audit as moderating variable on the quality of financial statement of the local government in Bangli Regency.

\section{STUDY LITERATURE AND REVIEW}

Each head of the local apparatus as the user of the budget in the implementation of government accountability, in particular the implementation of the local government budget, Anggaran Pendapatan dan Belanja Daerah (APBD), is required to carry out accounting for financial transactions, assets, debts and equity funds within its responsibility. Recording in the accounting process is used as material in preparing the financial statement, which is a media for an entity, in this case the government, to be responsible for its financial performance to the public, so the government has to be able to present qualified information in financial statement, where the information presented has to meet the qualitative characteristics of the government financial statement.

The new standard required local goverment to prepare seven reports, namely Budget Realization Statements, Operational Report, Statement of Vol. 28, No. 3 December 2020

(C) Centre for Indonesian Accounting and Management Research Postgraduate Program, Brawijaya University 
Changes in Budget Surplus, Balance Sheet, Cash Flows Statement, Statement of Changes in Equity, and Notes to the Financial Statements, increases the complexity of local government financial statements (Nurkholis and Affandi, 2019). The accounting understandibility of the government apparatus is required to produce qualified financial statement, which is interpreted as the ability of employees to manage accounting information and then compile the information in the form of financial statement prepared in accordance with the Governmental Accounting Standards. The existence of accounting understandibility in the process of preparing and presenting financial statement is a matter that greatly affects the quality of government financial statement. When employees are able to process information and understand the accounting policies set by the government, the financial statement prepared and presented will be in accordance with standards, quality and relevant for decision making.

Researches conducted by Diani (2014), Purwanti (2014), and Nudilah (2016) suggested that the level of accounting understandibility had a positive effect on the quality of financial statement, so that accounting understandibility is required to prepare the financial statement. To improve the quality of financial statement, the contents in financial statement have to be understood by both the makers, readers and users of the financial statement, and also the 
employees involved in the preparation of financial statement have to understand and understand how the accounting process is carried out, so that with intelligence or knowledge about accounting, the financial statement would be qualified and avoid the misinformation. However, this is contrary to the result of research conducted by Nova (2015) which stated that the accounting understandibility had no effect on the quality of government financial statement, the higher the understanding of accounting would not affect the quality of financial statement produced. The local government's working unit (Satuan Perangkat Kerja Daerah/SKPD) were not able to prove that in each agency where they worked were not able to produce a qualified government financial statement and accounting understandibility could not improve their understanding in analyzing the evidence of financial transactions.

Besides accounting understandibility, human resource competency is a key element in providing government financial statement. The accoutning change from cash-basis to accrual is not just a technical matter of recording transactions, but requires accounting policies in analyzing the existing transactions. The success of an entity in achieving its goals is largely determined by the quality and ability of the human resources in it. Someone who is competence would work using knowledge and skills, so they could work easily, quickly and minimize the errors in preparing the financial statement. 
Humairoh (2013), Ihsanti (2014), Udiyanti (2014), and Wati, et al. (2014) suggested that competence had positive effect on the quality of government financial statement, because with the competency of human resources, it could be seen whether government has carried out its duties and functions professionally, effectively and efficiently, so that it would encourage the realization of qualified financial statement. This research is also supported by Setyowati (2014), Novalia (2015), Sapitri (2015), Hanifa (2016) and Pramudityo (2017) who suggested that competency had major influence in the process of preparing financial statement, so that it had qualified information values for information users. This is contrary to the result of research conducted by Sukmaningtyas (2017) which suggested that human resource competency had negative significant effect on the quality of financial statement. It was difficult for employees to understand what need to be done because the level of education of employees who did not have an accounting background led to low competency, but the quality of financial statement produced remains to improve.

Thereafter, in assessing the accuracy of the implementation of organizational policies and making corrections if there were irregularities, an internal audit role is required, which is the inspectorate as an internal supervisory apparatus of the local government and as an independent 
assessment media in government organizations to evaluate the financial statement to be free from material errors, so the role of internal audit could assist the government in preparing the qualified financial statement.

Nova (2015) that suggested that the role of internal audit had positive effect on the quality of financial statement, where the better the role of internal audit, the better the quality of financial statement produced. So the existence of an internal audit/inspectorate role could assist local government in preparing qualified financial statement. Diani (2014) also proved that the role of internal audit had positive effect on the quality of financial statement. Previous research has shown that better quality of financial statements and good governance resulted as implementation of public sector audit conducted by the local level inspectorate (Satyal, 2006; Al-Shetwi et.al, 2011). Public sector audit consist of financial audit, performance audit and investigative were supervised and inspected regularly by auditors in order to monitoring and overseeing the entity's results of operations. Thus, the function and role of government auditors is also very important (Rahmatika, 2014).

\section{RESEARCH METHODOLOGY}

The population of this study was the civil cervants of local government in Bangli Regency in 29 local apparatuses. The sampling method used was the nonVol. 28, No. 3 December 2020

(C) Centre for Indonesian Accounting and Management Research Postgraduate Program, Brawijaya University 
probability sampling which was the purposive sampling approach. Respondents in this study were 58 civil servants who worked in the financial section of the local apparatus in Bangli Regency. The data source was primary data in the form of questionnaire. Questionnaires were given to respondents, which were the administration officials and treasurers in each local apparatus as financial statement makers. In answering the questionnaires, respondents used a Likert scale with a rating scale from 1 to 5 to answer the questions which were (1) strongly disagree, (2) disagree, (3) doubt, (4) agree and (5) strongly agree. The analysis technique used was the multiple linear regression analysis.

The independent variable was the accounting understandibility $\left(X_{1}\right)$ and human resource competency $\left(\mathrm{X}_{2}\right)$. The moderating variable was the role of internal audit $\left(X_{3}\right)$. The accounting understandibility referred to the understanding of the financial administration officials and expenditure treasurers of the local government in Bangli Regency in preparing the financial statement, because reliable intelligence and knowledge would not lead the quality of financial statement to misinformation. The indicators of the accounting understandibility consisted of the understanding of basic equation in accounting which were the understanding of assets, liabilities and equity. Human resource competency referred to the ability of the financial administration officials and expenditure treasurers of the local government in 
Bangli Regency in carrying out their duties and positions as the local government financial statement makers. The indicators of the human resource competency were the components contained in competency, which were knowledge, skills and behavior. The internal audit role referred to the role of the Bangli Regency inspectorate as the government internal supervisory apparatus by conducting a review and evaluation for providing value added and improving the organizational operations. The indicators of the internal audit role consisted of the audit process carried out through audit planning, audit implementation and audit reporting.

The dependent variable was the quality of financial statement $(Y)$. The quality of financial statement referred to the qualitative characteristics of financial statement stated in PP No. 71 of 2010. The indicators of the quality of financial statement consisted of the level of relevance, level of reliability, level of comparability and level of understanding.

\section{RESULT AND DISCUSSION}

Validity test is used to measure the validity of a questionnaire. The minimum requirement to be considered eligible is if the pearson correlation value is $>0.30$. The validity test result is shown in Table 1 below:

Tabel 1. Validity Test Result

Vol. 28, No. 3 December 2020

(C) Centre for Indonesian Accounting and Management Research Postgraduate Program, Brawijaya University 


\begin{tabular}{|c|c|c|c|c|}
\hline No. & Variable & $\begin{array}{l}\text { Question } \\
\text { Items }\end{array}$ & $\begin{array}{l}\text { Pearson } \\
\text { Correlation }\end{array}$ & Description \\
\hline \multirow[t]{9}{*}{1} & Accounting & $\mathrm{X} 1.1$ & 0.611 & Valid \\
\hline & Understandibility & $X 1.2$ & 0.752 & Valid \\
\hline & & $X 1.3$ & 0.782 & Valid \\
\hline & & $X 1.4$ & 0.709 & Valid \\
\hline & & X1.5 & 0.710 & Valid \\
\hline & & X1.6 & 0.767 & Valid \\
\hline & & $X 1.7$ & 0.825 & Valid \\
\hline & & $\mathrm{X} 1.8$ & 0.748 & Valid \\
\hline & & X1.9 & 0.751 & Valid \\
\hline \multirow[t]{10}{*}{2} & Human Resource & $X 2.1$ & 0.609 & Valid \\
\hline & Competency $\left(X_{2}\right)$ & Y? & ברד ח & Yalid \\
\hline & & & & \\
\hline & & $\times 2.3$ & 0.727 & Valid \\
\hline & & $\times 2.4$ & 0.523 & Valid \\
\hline & & $\times 2.5$ & 0.486 & Valid \\
\hline & & $\times 2.6$ & 0.711 & Valid \\
\hline & & $\times 2.7$ & 0.605 & Valid \\
\hline & & $X 2.8$ & 0.508 & Valid \\
\hline & & $\times 2.9$ & 0.488 & Valid \\
\hline 3 & & X3.1 & 0.519 & Valid \\
\hline
\end{tabular}


160 Evaluating The Role of Internal Audit. . . . .

\begin{tabular}{|c|c|c|c|c|}
\hline & \multirow{2}{*}{$\begin{array}{l}\text { The Role of Internal } \\
\text { Audit }\left(\mathrm{X}_{3}\right)\end{array}$} & $X 3.2$ & 0.748 & Valid \\
\hline & & X3.3 & 0.701 & Valid \\
\hline & & $X 3.4$ & 0.768 & Valid \\
\hline & & $\times 3.5$ & 0.831 & Valid \\
\hline & & X3.6 & 0.646 & Valid \\
\hline & & $X 3.7$ & 0.692 & Valid \\
\hline & & $X 3.8$ & 0.726 & Valid \\
\hline & & X3.9 & 0.540 & Valid \\
\hline \multirow[t]{9}{*}{4} & The Quality of & Y.1 & 0.702 & Valid \\
\hline & $\begin{array}{l}\text { Financial Statement } \\
\text { (Y) }\end{array}$ & Y.2 & 0.707 & Valid \\
\hline & & Y.3 & 0.701 & Valid \\
\hline & & Y.4 & 0.634 & Valid \\
\hline & & Y.5 & 0.738 & Valid \\
\hline & & Y.6 & 0.693 & Valid \\
\hline & & Y.7 & 0.706 & Valid \\
\hline & & Y.8 & 0.735 & Valid \\
\hline & & Y.9 & 0.744 & Valid \\
\hline
\end{tabular}

Source: Data processed, 2019

Based on Tabel 1, the result showed that each variable was able to express what should be measured and could reveal the researched data appropriately. 
The reliability test is used to determine whether the indicator or questionnaire used can be trusted or reliable as a variable measurement tool. According to (Ghozali, 2016: 47) a questionnaire is said to be reliable if someone's answer to the statement is consistent or stable from time to time. The requirement is if the Cronbach Alpha value $>0.70$. The reability test result is shown in Table 2 below:

Tabel 2. Reliability Test Result

\begin{tabular}{llcl}
\hline No. & \multicolumn{1}{c}{ Variable } & $\begin{array}{c}\text { Alpha } \\
\text { Cronbach }\end{array}$ & Description \\
\hline 1 & Accounting Understandibility $\left(\mathrm{X}_{1}\right)$ & 0.891 & Reliable \\
2 & Human Resource Competency $\left(\mathrm{X}_{2}\right)$ & 0.761 & Reliable \\
3 & The Role of Internal Audit $\left(\mathrm{X}_{3}\right)$ & 0.862 & Reliable \\
4 & The Quality of Financial Statement & 0.873 & Reliable \\
& $(\mathrm{Y})$ & & \\
\hline
\end{tabular}

Source: Data processed, 2019

Based on Tabel 2, the statement in the questionnaire were delcared reliable.

\section{Classical Assumption Test}

The normality test is used to test whether the data is normally distributed or not, using the Kolmogorof Smirnov method of analysis. This test is used to compare the probabilities obtained with a significance level of 0.05 . If the sig value $>0.05$ then the data is normally distributed. Based on the result of calculations using the Kolmogorov-Smirnov test, it suggested that the Unstandardized Residual value in the Asym column. Sig (2-tailed) was 0.306 
where the significance value was greater than $\alpha=(0.05)$, which meanns the residual data in this study were normally distributed.

The multicollinearity test was done in two ways, which are by looking at VIF (Variance Inflation Factor) and tolerance value. If $\mathrm{VIF}<10$ and tolerance value $>0.10$, it means no symptoms of multicollinearity. The results of multicollinearity test suggested that the tolerance value from variables were greater than 0.10 which were the accounting understandibility was 0.838 , the human resource competency was 0.716 , the role of internal audit was 0.609 , the interaction of the accounting understandibility * the role of internal audit was 0.238 and the interaction of the human resource competency * the role of internal audit was 0.222 . The VIF value of the independent variable was smaller than 10 , which were the accounting understandibility was 1.194 , the human resource competency was 1.396 , the role of internal audit was 1.642 , the interaction of the accounting understandibility * the role of internal audit was 4.195 and the interaction of the human resource competency ${ }^{*}$ the role of internal audit was 4,498 . Then it could be concluded that there was no multicollinearity between the independent variables in this regression model.

The multicollinearity test was done in two ways, which are by looking at VIF (Variance Inflation Factor) and tolerance value. If VIF $<10$ and tolerance value $>0.10$, it means no symptoms of multicollinearity. The results of 
multicollinearity test suggested that the tolerance value from variables were greater than 0.10 which were the accounting understandibility was 0.838 , the human resource competency was 0.716 , the role of internal audit was 0.609 , the interaction of the accounting understandibility * the role of internal audit was 0.238 and the interaction of the human resource competency * the role of internal audit was 0.222 . The VIF value of the independent variable was smaller than 10 , which were the accounting understandibility was 1.194 , the human resource competency was 1.396 , the role of internal audit was 1.642 , the interaction of the accounting understandibility * the role of internal audit was 4.195 and the interaction of the human resource competency ${ }^{*}$ the role of internal audit was 4,498 . Then it can be concluded that there was no multicollinearity between the independent variables in this regression model.

The heteroscedasticity test was done by the Glejzer test, which was by regressing the absolute residual value with the independent variable. The criteria used was if the probability value $\geq 0.05$ then heteroscedasticity does not occur. Based on the result of the Glejser test, the significance value of all variables is greater than 0.05 , which were the accounting understandibility was 0.955 , the human resource competency was 0.996 , and the role of internal audit was 0.798 , the interaction of the accounting understandibility ${ }^{*}$ the role of internal audit was 0.064 and the interaction of the human resource competency 
* the role of internal audit was 0.089 . Therefore, it could be concluded that in the regression model heteroscedasticity did not occur.

\section{Moderated Regression Analysis}

The analytical model used in this study was the moderated regression analysis by interaction testing. Moderated regression analysis was used to examine the effect of accounting understandibility, human resource competency and the role of internal audit as a moderating variable on the quality of the financial statement of local government in Bangli Regency.

\section{Hypothesis Testing}

The adjusted determination coefficient $\left(R^{2}\right)$ is used to find out the ability of the model ability in explaining variations in the dependent variable (Y). The result is shown in Table 3 below:

Tabel 3. Determination Coefficient

\begin{tabular}{llll}
\hline$R$ & R Square & Adjusted R Square & Sig. \\
0.867 & 0.752 & 0.728 & 0.000 \\
\hline
\end{tabular}

Source: Data processed, 2019

Table 3 showed that the Adjusted R Square value was 0.728 . This means that $72.8 \%$ of the variation in the quality of financial statement could be explained by the accounting understandibility, human resource competency and the role of internal audit, and the remaining $37.2 \%$ was explained by other factors outside the research model.

Vol. 28, No. 3 December 2020

(C) Centre for Indonesian Accounting and Management Research Postgraduate Program, Brawijaya University 
The simultaneous test ( $\mathrm{F}$ test) is conducted to determine whether all independent variables included in this regression model have simultaneous effect on the dependent variable. The $\mathrm{F}$ test result is shown in Table 4 below:

Tabel 4. F Test Result

\begin{tabular}{cc}
\hline$F$ & Sig. \\
\hline 0.728 & 0.000 \\
\hline
\end{tabular}

\section{Source: Data processed, 2019}

The $F$ test value was 31.556 with a significance level of 0.000 was smaller than 0.05 , the regression model used was appropriate or fit, which means accounting understandibility, human resource competency, the role of internal audit and interaction variables simultaneously or together affected the quality of financial statement.

Hypothesis testing is done by $\mathrm{t}$ test. This test shows the influence of one explanatory/independent variable individually in explaining the variation of the dependent variable. If the significance value of $t \leq 0.05$, then the independent variable individually influences the dependent variable and if the significance value of $t>0.05$ then the independent variable has no effect on the dependent variable. $T$ test result is shown in the following Table 5:

Table 5. T Test Result

\begin{tabular}{lccc}
\hline Model & $\begin{array}{c}\text { Unstandardized } \\
\text { Coefficients }\end{array}$ & T & Sig. \\
\hline
\end{tabular}




\begin{tabular}{|c|c|c|c|c|}
\hline & $\mathrm{B}$ & Std. Error & & \\
\hline (Constant) & -10.498 & 5.485 & $\begin{array}{c}- \\
1.914\end{array}$ & 0.061 \\
\hline Accounting Understandibility & 0.904 & 0.100 & 8.998 & 0.000 \\
\hline Human Resource Competency & 0.909 & 0.117 & 7.791 & 0.000 \\
\hline The Role of Internal Audit & 0.075 & 0.126 & 0.595 & 0.554 \\
\hline $\begin{array}{l}\text { Accounting Understandibility * The Role } \\
\text { of Internal Audit }\end{array}$ & 0.002 & 0.004 & 0.437 & 0.664 \\
\hline $\begin{array}{l}\text { Human Resource Competency } * \text { The } \\
\text { Role of Internal Audit }\end{array}$ & -0.017 & 0.006 & $\begin{array}{c}- \\
3.137\end{array}$ & 0.003 \\
\hline
\end{tabular}

Source: Data processed, 2019

The Effect of Accounting Understandibility on The Quality of Financial

\section{Statement}

The regression coefficient value for the accounting understandibility variable was 0.904 with a significance value of 0,000 was less than $\alpha=(0.05)$. This means that the accounting understandibility had positive effect on the quality of financial statement, thus $\mathrm{H} 1$ was accepted. Accounting understandibility of the financial administration officials and treasurers of the local government in Bangli Regency had positive effect on the quality of the local government financial statement. The higher the accounting understandibility, the local governmnet is more able to improve the quality of the financial statement produced.

Vol. 28, No. 3 December 2020

(C) Centre for Indonesian Accounting and Management Research Postgraduate Program, Brawijaya University 
Financial statement is a form of accountability mechanism to create public accountability, where the financial statement presents information that is useful for users. This is in line with the agency theory which states that the government as an agent has an obligation to provide responsibility, present, report and disclose all activities and activities that are within its responsibilities in the form of financial statement to the public (principal) as users of information, so in the presenting the financial statement prepared by the government has to meet the components of financial statement so that the quality of the financial statement produced becomes better.

Therefore, the accounting understandibility is highly required so that the financial statement prepared would have a high-quality. The accounting understandibility is the ability or intelligence of self in understanding or knowing correctly about accounting, especially regarding the basic accounting equation, where by understanding the basic accounting equation that is owned by the financial administration officials and the treasurers of the local apparatus, would be used as a tool to facilitate identification transactions, so that with a good accounting understandibility, the quality of the financial statement produced would also be high qualified.

The Effect of Human Resorce Competency on The Quality of Financial Statement

Vol. 28, No. 3 December 2020 (C) Centre for Indonesian Accounting and Management Research Postgraduate Program, Brawijaya University 
The regression coefficient value for the human resource competency variable was 0.909 with a significance value of 0,000 which was less than $\alpha$ $=(0.05)$. This means that the human resource competency had positive effect on the quality of financial statement, thus $\mathrm{H} 2$ was accepted. Based on the demographic data of the respondents, it showed that the employees involved in financial administration who were S1 graduated (bachelor degree) rank highest at $65.5 \%$, this means that most of the employees involved in financial administration had higher education. Human resource competency is a key element in providing government financial statement. Someone who has competence would work using knowledge and skills, so they could work easily, quickly and minimize the errors in preparing the financial statement. When human resources fail to understand and apply accounting, it would lead to the errors in the financial statement produced and not in accordance with the established standards.

The Effect of The Role of Internal Audit on The Relation Between Accounting Understandibility and The Quality of Financial Statement

The regression coefficient value for the interaction variables of the role of internal audit with the accounting understandibility was 0.002 with a significance value of 0.664 which was greater than $\alpha=(0.05)$. This means that the role of internal audit was not a moderating variable that was able to Vol. 28, No. 3 December 2020

(C) Centre for Indonesian Accounting and Management Research Postgraduate Program, Brawijaya University 
strengthen/weaken the relation between the accounting understandibility and the quality of financial statement, thus $\mathrm{H} 3$ was rejected. In this case, it can be concluded that the higher level of accounting understandibility possed by financial administration officials and treasurers of the local government in Bangli Regency had provided sufficient assureance in providing qualified financial statement without being moderated by the role of internal audit. A theory that provides a basis for explaining a person's behavior is a psychological theory of attribution proposed by Fritz Heider (1958). Heider examined how individuals determine whether another person's behaviour is internally caused (e.g. nature, character, attitude, etc.) or externally caused (e.g. pressure of certain situations or circumstances) which would affect the behavior of individuals in dealing with certain situations. Attribution is generally defined as causal inferences people make about why people behave as they do (Floyd et al., 2017). Floyd et al. (2017) stated that almost all accounts of attribution theory start by distinguishing between personal and situastional attributions for behavior. The person attribution, also called an internal attribution, "ascribes the causes of behavior to personal dispositions, traits, abilities, and feelings" (Weiten in Floyd et al., 2017). The financial administration officials and treasurers of the local government in Bangli Regency who were the respondents in this research were dominated by the internal attribution. Their abilities related to level of 
accounting understandibility had provided sufficient assureance in providing qualified financial statement, so that their behavior was likely to dismiss the role of internal audit.

The Effect of The Role of Internal Audit on The Relation Between Human Resource Competency And The Quality of Financial Statement

The regression coefficient value for the interaction variables of the role of internal audit with the human resource competency was -0.017 with a significance value of 0.003 which was smaller than $\alpha=(0.05)$. This means that the role of the internal audit was a moderating variable, thus $\mathrm{H} 4$ was accepted. However, the direction of the regression coefficient marked negative, indicates that the role of internal audit had effect that was able to weaken the positive relation between human resource competency and the quality of financial statement.

The role of the internal audit would be able to assist the government in preparing financial statement to determine the reliability of financial information produced by the local apparatus. The audit would determine whether the financial statement have been presented in accordance with establihed standards. The input provided by the inspectorate as an internal audit of the local government would lead to the realization of financial 
statement in accordance with the Governmental Accounting Standards, so it would improve the quality of financial statement.

Meanwhile, according to the attribution theory, a person's behaviour is whether internally caused (e.g. nature, character, attitude, etc.) or externally caused (e.g. pressure of certain situations or circumstances) which would affect the behavior of individuals in dealing with certain situations. In this case, the behavior of the financial administration officials and treasurers of the local government in Bangli Regency who were the respondents in this research were dominated by the situation attribution. The situation attribution, also called an external attribution, "ascribes the causes of behavior to situational demands and environmental constraints" (Weiten in Floyd et al., 2017). The human resource competency possed by financial administration officials and treasurers of the local government in Bangli Regency seemed to be confined by the role of internal auditor, in this case, they might feel working under pressure. So that the role of internal auditor precisely weakened the positive relation between human resource competency and the quality of financial statement.

However, the internal auditor as part of internal control process has limitations because internal control would not be able to prevent all problems that occur. Internal control function is only to provide reasonable assurance on achieving organizational goals. The inherent limitations of internal control 
practices are human factors related to the decision making process, lack of information and changes in structure, systems or procedures that could be confusing. This is what might cause a negative interaction between the role of internal audit and human resource competence on the quality of financial statements. This shows the importance of understanding, integrity and commitment to the existence of an internal control process that requires a consistent internalization process as well as a continuous monitoring and improvement process.

\section{CONCLUSION}

This study aimed to obtain empirical evidence about the effect of accounting understandability, human resource competency and the role of internal audit as moderating variable on the quality of financial statement, by taking a sample of 58 people consisting of financial administration officials and treasurers in the local apparatus of the local government in Bangli Regency. The result of this study suggested that the accounting understandibility and human resource competency had positive effect on the quality of financial statement. By having good accounting understandibility which is the ability of self in understanding or knowing about accounting that is owned, would be used as a tool to facilitate identification of transactions, so that with a good understanding 
of accounting, the quality of financial statement would also be high-qualified. The success of an entity in achieving its goals is also largely determined by the quality and ability of the human resources within it.

Meanwhile, the role of internal audit had no effect on the relation between the accounting understandibility and the quality of financial statement. This shows that the higher level of accounting understandibility possed by financial administration officials and treasurers of the local government in Bangli Regency had provided sufficient assureance in providing qualified financial statement without being moderated by the role of internal audit. In this case, based on the attribution theory, the respondents in this research were dominated by the internal attribution. Their abilities related to level of accounting understandibilityhad provided sufficient assureance in providing qualified financial statement, so that their behavior was likely to dismiss the role of internal audit.

Furthermore, the role of the internal audit was successfully proven as a moderating variable in the relation of human resource competency and the quality of financial statement. The role of the inspectorate in correcting errors in the preparation of financial statement and the input provided by the inspectorate might weaken the competence of human resources so that it could reduce the quality of financial statement. The behavior of the respondents in 
this research were dominated by the situation attribution which is stated under the attribution theory. Their human resource competency seemed to be confined by the role of internal auditor, in this case, they might feel working under pressure. So that the role of internal auditor precisely weakened the positive relation between human resource competency and the quality of financial statement. In additional, the inherent limitations of internal control practices are human factors related to the decision making process, lack of information and changes in structure, systems or procedures that could be confusing. This shows the importance of understanding, integrity and commitment to the existence of an internal control process that requires a consistent internalization process as well as a continuous monitoring and improvement process.

Future research can expand the research area in other areas, for example in the local apparatus in the Province of Bali and consider other variables that are believed to having direct or indirect effects on the quality of financial statement such as the use of information technology, the application of local financial accounting systems and the application of Governmental Accounting Standards. An extend study of internal audit quality could be considered also as the quality of financial reporting affected by efectiveness internal auditor 
monitoring reflected by independence (competence) internal auditor (Abbot et.al, 2016; Christopher, 2019).

\section{REFERENCES}

Abbot, Lawrence.J, Brian Daugherty, Susan Parker, Gary F. Peters. 2016. Internal Audit Quality and Financial Reporting Quality: The Joint of Importance and Competence. Journal of Accounting Research. Vol. 54. Issue 1 March 2016: 3-40.

Al-Shetwi, Mohammed \& Ramadili, Shamsher \& Hassan, Taufiq \& Chowdury, Shah \& Muhamad Sori, Zulkarnain. 2011. Impact of internal audit function (IAF) on financial reporting quality (FRQ): Evidence from Saudi Arabia. African Journal of Business Management. Vol.5.

Christopher, J. 2019. The Failure of Internal Audit: Monitoring Gaps and a Case for a New Focus. Journal of Management Inquiry. Vol. 28. No. 4: 472-483. doi: $10.1177 / 1056492618774852$.

Diani, Dian Irma. 2014. Pengaruh Pemahaman Akuntansi, Pemanfaatan Sistem Akuntansi Keuangan Daerah dan Peran Internal Audit terhadap Kualitas Laporan Keuangan Pemerintah Daerah (Studi Empiris pada Satuan Kerja Perangkat Daerah di Kota Pariaman). Jurnal Akuntansi. Vol 2. No 1: 1-23. Universitas Negeri Padang

Elsye, Rosmery. 2016. Dasar-dasar Akuntansi Akrual Pemerintah Daerah. Cetakan 1. Bogor: Ghalia Indonesia.

Ghozali, Imam. 2016. Aplikasi Analisis Multivariate. Edisi 8. Semarang: BPFE Universitas Diponogoro. 
Gramling, Audrey A., Nur Irem Nuhoglu \& David A. Wood. 2013. A Descriptive Study of Factors Associated with the Internal Audit Function Policies Having an Impact: Comparisons Between Organizations in a Developed and an Emerging Economy. Journal Turkish Studies. Vol. 14. No. 3: 581606. DOI: $10.1080 / 14683849.2013 .833019$

Floyd, Kory., Paul Schrodt dan Larry Erbert. 2017. Exploring Communication Theory: Making Sense of Us. Edisi 1. London: Routledge.

Humairoh, Iftitah Dian. 2013. Pengaruh Kompetensi SDM Terhadap Kualitas Laporan Keuangan Pemerintah daerah (studi empiris pada SKPD Kabupaten Jember). Artikel IImiah Mahasiswa 2013. Universitas Jember. Hanifa, Lia. 2016. Pengaruh Kompetensi Pengelola Keuangan dan Sistem Akuntansi Keuangan Daerah terhadap Kualitas Laporan Keuangan. Jurnal Progres Ekonomi Pembangunan. Vol 1. No 2: 65-80. Universitas Halu Oleo Kendari.

Ihsanti, Emilda. 2014. Pengaruh Kompetensi SDM dan Penerapan Sistem Akuntansi Keuangan Daerah Terhadap Kualitas Laporan Keuangan Daerah (studi empiris pada SKPD Kab. Lima Puluh Kota). Jurnal Akuntansi. Vol 2. No 2. Universitas Negeri Padang.

Islamiyah, Yunita., Eko Ganis Sukoharsono, and Rosidi. 2017. Public Sector's Managerial And Financial Accountability (A Study Of New Institutional Theory Perspective). The International Journal of Accounting and Business Society. Vol 25. No. 1: 1-18.

Kewo, Cecilia Lelly., dan Nunuy Nur Afiah. 2017. Does Quality of Financial Statement Affected by Internal Control System and Internal Audit?International Journal of Economics and Financial Issues. Vol. 7. No. 2: $568-573$. 
Nova, Wati Sri. 2015. Pengaruh Pemahaman Akuntansi, Komitmen Karyawan dan Peran Internal Audit terhadap Kualitas Laporanan Keuangan Pemerintah Daerah (studi empiris pada SKPD di Kabupaten Sijunjung). Jurnal Akuntansi. Universitas Negeri Padang.

Novalia, Irma. 2015. Pengaruh Kompetensi SDM, Penerapan Sistem Akuntansi Keuangan Daerah dan Sistem Pengendalian Intern Terhadap Kualitas Laporan Keuangan Pemerintah daerah (studi empiris pada dinas SKPD kota Surakarta). Naskah Publikasi: 1-11. Universitas Muhammadiyah Surakarta.

Nudilah, Miftahul Janatun. 2016. Pengaruh Etika Kepemimpinan, Fungsi Badan Pengawas dan tingkat pemahaman akuntansi terhadap kualitas laporan keuangan pada lembaga perkreditan desa (LPD) di kota Denpasar. Skripsi. Universitas Mahasaraswati Denpasar.

Nurkholis., and Arlisya Tika Affandi. 2019. The Utilization Of Government Financial Statements By Executives: The Case Of Local Governments In Indonesia. The International Journal of Accounting and Business Society. Vol 27. No. 3: 56-78.

Peraturan Pemerintah Nomor 71 Tahun 2010 tentang Standar Akuntansi Pemerintahan.

Peraturan Pemerintah Republik Indonesia Nomor 60 Tahun 2008 Tentang Sistem Pengendalian Intern Pemerintah.

Prawitt DF, Smith JL, Wood DA. 2009. Internal Audit Quality and Earnings Management. Accounting Review. Vol. 84. No. 4: 1255-1280.

Purwanti, Meilani., dan Wasman. 2014. Pengaruh Pemahaman Akuntansi, Pemanfaatan Sistem Informasi Akuntansi dan Peran Internal Audit 
terhadap Kualitas laporan Keuangan. Esensi Jurnal Bisnis dan Manajemen. Vol 4. No 3: 61-75. STIE Stembi Bandung.

Pramudityo, Bagus. 2017. Pengaruh Kompetensi SDM, Pemanfaatan Sistem Informasi Akuntansi Keuangan Daerah, Sistem Pengendalian Intern dan Peran Internal Audit terhadap Kualitas Laporan Keuangan Pemerintah Daerah. Naskah Publikasi. Universitas Muhammadiyah Surakarta.

Rahmatika, Dien Noviany. 2014. The Impact of Internal Audit Function

Effectiveness on Quality of Financial Reporting and its Implications on Good Government Governance Research on Local Government Indonesia. Research Journal of Finance and Accounting. Vol. 5. No. 18: 64-7.

Sapitri, Ni Made Trisna. 2015. Pengaruh Kapasitas SDM, Pengendalian Internal Akuntansi Dan Pemanfaatan Teknologi Informasi Terhadap Kualitas laporan Keuangan (studi kasus koperasi simpan pinjam di kecamatan Buleleng). e-journal S1 Ak Universitas Pendidikan Ganesha Singaraja. Vol 3. No 1.

Satyal, Ramesh R. 2006. Audit Profile: Office of the Auditor General of Nepal. International Journal of

Government Auditing; Oct 2006; 33, 4; ABI/INFORM Global pg. 26

Sawyer, Lawrence B. 2005. Internal Auditing. Edisi 5. Jakarta: Salemba Empat. Setyowati, Lilis., dan Wikan Isthika. 2014. Analisis Faktor yang Mempengaruhi

Kualitas Laporan Keuangan Daerah pada Pemerintah Kota Semarang. Proceedings SNEB: 1-8. Universitas Dian Nuswantoro Semarang.

Sudarmanto, 2015. Kinerja dan Pengembangan Kompetensi SDM. Cetakan ketiga. Yogyakarta: Pustaka Belajar.

Sukmaningtyas, Shinta. 2017. Pengaruh Sistem Pengendalian Intern, Kompetensi SDM dan Pemanfaatan Teknologi Informasi terhadap Kualitas 
Laporan Keuangan Pemerintah Daerah. Naskah Publikasi. Universitas Muhammadiyah Surakarta.

Susanto, Dwi Setiawan., Made Sudarma, Sutrisno, and Rosidi. 2019. Judgement State Auditor On Audit Opinion For Government Financial Statement With Perspective Hermeneutic Phenomenology. The International Journal of Accounting and Business Society. Vol 27. No. 2: 27-54.

Udiyanti, Ni Luh Nyoman Ari., Anantawikrama Tungga Atmaja dan Nyoman Ari Surya Darmawan. 2014. Pengaruh Penerapan Standar Akuntansi Pemerintahan, Sistem Pengendalian Internal, Dan Kompetensi Staf Akuntansi Terhadap Kualitas Laporan Keuangan Pemerintah daerah (studi kasus pada SKPD Kabupaten Buleleng). e-journal S1 AK Universitas Pendidikan Ganesha Singaraja. Vol 2. No 1.

Wati, Kadek Desiana., Nyoman Trisna Herawati dan Ni Kadek Sinarwati. 2014. Pengaruh Kompetensi SDM, Penerapan SAP dan Sistem Akuntansi Keuangan Daerah terhadap Kualitas Laporan Keuangan Daerah Kabupaten Buleleng. e-journal S1 Ak Universitas Pendidikan Ganesha Singaraja. Vol 2. No 1.

Zeyn, Elvira. 2018. The Effect of Internal Audit Quality on Financial Accountability Quality at Local Government. Journal of Accounting, Business and Fiance Research. Vol. 4. No.2: 74-82. 
180 Evaluating The Role of Internal Audit. . . . .

Vol. 28, No. 3 December 2020

(C) Centre for Indonesian Accounting and Management Research Postgraduate Program, Brawijaya University 